\title{
The effect of human chorionic gonadotrophin on the expression of progesterone receptors in human luteal cells in vivo and in vitro
}

\author{
W Colin Duncan, Eva Gay and Jacqueline A Maybin \\ Obstetrics and Gynaecology, Department of Reproductive and Developmental Sciences, University of Edinburgh, \\ Royal Infirmary of Edinburgh - Little France, 49 Little France Crescent, Old Dalkeith Road, Edinburgh \\ EH16 4SB, UK
}

Correspondence should be addressed to W C Duncan; Email: W.C.Duncan@ed.ac.uk

\begin{abstract}
The human corpus luteum expresses genomic progesterone receptors (PRs) suggesting that progesterone may have an autocrine or paracrine role in luteal function. We hypothesised that the reduction in luteal PR reported in the late-luteal phase augmented progesterone withdrawal and had a role in luteolysis. We therefore tested the hypothesis that luteal rescue with human chorionic gonadotrophin (hCG) would maintain PR expression. PR was immunolocalised to different cell types in human corpora lutea $(n=35)$ from different stages of the luteal phase and after luteal rescue with exogenous hCG. There was no change in the staining intensity of theca-lutein cell or stromal cell PR throughout the luteal phase or after luteal rescue. In the late-luteal phase, granulosa-lutein cell PR immunostaining was reduced $(P<0.05)$ but the trend to reduction was also seen after luteal rescue with hCG $(P=\mathbf{0 . 0 5 5})$. To further investigate the effect of hCG on granulosa-lutein cell PR expression, an in vitro model system of cultured human luteinised granulosa cells was studied. Cells were cultured for 12-13 days exposed to different patterns of hCG and aminoglutethamide to manipulate progesterone secretion $(P<0.0001)$. Expression of PR A/B and PR B isoforms was examined by quantitative real-time RT-PCR. PR A/B mRNA was lower $(P<0.05)$ after $11-13$ days of culture than after 7 days of culture. This reduction could not be prevented by hCG in the presence $(P<0.05)$ or absence $(P<0.05)$ of stimulated progesterone secretion. The expression of PR B mRNA showed a similar pattern $(P=0.054)$. Simulated early pregnancy in vivo and hCG treatment of luteinised granulosa cells in vitro did not appear to prevent the down-regulation of PR seen during luteolysis.

Reproduction (2005) 130 83-93
\end{abstract}

\section{Introduction}

In a non-conception cycle, the human corpus luteum undergoes luteolysis with a loss of functional and structural integrity. The molecular events involved in luteolysis and how they are prevented by exposure to human chorionic gonadotrophin (hCG) remain unclear (Behrman et al. 1993, Duncan 2000). As hCG has effects on macrophages (Duncan et al. 1998a), fibroblasts (Duncan et al. 1998b) and blood vessels (Wulff et al. 2001), that do not express luteinising hormone $(\mathrm{LH}) / \mathrm{hCG}$ receptors, paracrine molecules must have important roles in luteal function (Duncan 2000).

One important potential paracrine molecule is progesterone itself (Stouffer 2003). It is clear that the human corpus luteum has genomic receptors to the progesterone it produces (Suzuki et al. 1994). These receptors are primarily localised to stromal fibroblasts, granulosa-lutein cells and theca-lutein cells (Maybin \& Duncan 2004). In other endocrine tissues, notably the endometrium, progesterone reception and withdrawal have key roles in the maintenance of function and tissue remodelling (Salamonsen et al. 1997, Curry \& Osteen 2003). While the exact role of progesterone in the corpus luteum is not clear (Stouffer 2003), several effects of progesterone on luteal cells have been described.

The steroidogenic cells that secrete progesterone express progesterone receptors (PRs) (Hild-Petito \& Fazleabas 1997, Maybin \& Duncan 2004) and it has been suggested that progesterone itself is involved in its own synthesis (Rothchild 1996). Progesterone can directly promote luteinised granulosa cell survival (Makrigiannakis et al. 2000) and influence the expression of $\mathrm{LH}$ receptors (Jones et al. 1992) and steroidogenic enzymes (Chaffin et al. 2000). In addition, progesterone has been implicated in the control of the tissue inhibitor of metalloproteinase-1 
expression in luteinised granulosa cells (Morgan et al. 1994). It is therefore possible that progesterone withdrawal has direct effects on steroidogenic cell function.

In the late-luteal phase, progesterone concentrations fall. This progesterone withdrawal is potentially facilitated further by the reduced expression of luteal genomic PRs in the late-luteal phase (Suzuki et al. 1994, Hild-Petito \& Fazleabas 1997). We hypothesised that the reduction of PR expression in the late-luteal phase did augment progesterone withdrawal and therefore had a role in luteolysis. If this were the case we believed that luteal rescue with hCG would be associated with maintenance of PR expression.

We have developed a system to collect and study carefully dated human corpora lutea from throughout the luteal phase. In addition, we have been able to study luteal rescue by treating women with exogenous hCG to mimic the hormonal changes of early pregnancy prior to collection of the corpus luteum (Duncan et al. 1996, 1998a, 1999). This has allowed us to study the late-luteal corpus luteum in the absence and presence of hCG, where progesterone is withdrawn or maintained. In this study we have investigated the effect of hCG on the expression of PR in human corpora lutea and in cultures of luteinised granulosa cells.

\section{Materials and Methods}

\section{Source of reagents}

All reagents were obtained from Sigma Chemical Co. (Poole, Dorset, UK) unless otherwise stated. The mouse monoclonal antibody to human PR was obtained from Vector Laboratories Ltd (Peterborough, Cambs, UK). The polyclonal rabbit antibody to human $17 \alpha$-hydroxylase was kindly provided by Professor M R Waterman (Vanderbilt University, Nashville, TN, USA). The polyclonal rabbit antibody to human placental type I $3 \beta$-hydroxysteroid dehydrogenase (3$\beta$-HSD) was supplied by Professor Van Luu-The (CHUL Research Centre, Quebec, Canada). The mouse monoclonal antibody to aromatase was provided by Professor E Simpson (PHIMR, Clayton, Victoria, Australia).

\section{Collection of corpora lutea}

The Reproductive Medicine Subcommittee of the Lothian Medical Ethics Committee approved the collection of human tissue. Human corpora lutea $(n=35)$ were collected at the time of surgery from women undergoing hysterectomy for benign conditions as described previously (Duncan et al. 1998b). All women had regular cycles and had not received any form of hormonal treatment in the 3 months prior to taking part in the study. Prior to surgery, the women collected a daily early morning urine sample and the corpora lutea were dated on the basis of the urinary LH surge. Corpora lutea were classified as early luteal
$(\mathrm{LH}+1$ to $\mathrm{LH}+5) \quad(n=11)$, mid-luteal $(\mathrm{LH}+6$ to $\mathrm{LH}+10)(n=10)$ or late-luteal $(\mathrm{LH}+11$ to $\mathrm{LH}+14)$ $(n=9)$.

In addition, rescued corpora lutea were also collected as described previously (Illingworth et al. 1990, Duncan et al. 1996). Briefly, women $(n=5)$ received daily injections of hCG (Profasi; Serono Laboratories, Welwyn Garden City, Herts, UK) from LH +7 in daily doubling doses, starting at $125 \mathrm{IU}$, for 5-8 days until surgery. This regimen prevents luteolysis and mimics the hormonal changes of early pregnancy. Blood was taken for serum progesterone estimation on the day of surgery. In all cases, an endometrial biopsy was obtained from the uterus immediately after its removal and the dating of this tissue, by the methods of Li et al. (1988), confirmed the classification of the corpora lutea.

At operation, the whole corpus luteum was enucleated from the ovary by blunt dissection and the ovary oversewn. The tissue was immediately divided into radial blocks in order to ensure that the whole thickness of the gland was represented in any piece. In this study, a block of corpus luteum was fixed in $4 \%$ paraformaldehyde and processed into paraffin wax. In 12 cases, a block of tissue that had been snap frozen in liquid nitrogen was available for batch extraction of RNA.

\section{Immunohistochemistry}

Histological sections $(5 \mu \mathrm{m})$ were dewaxed, rehydrated, permeabilised with $0.1 \%$ Triton and incubated in $1 \%$ hydrogen peroxide for $30 \mathrm{~min}$. After rinsing, the sections were blocked with a 1:67 dilution of normal horse serum (Vector Laboratories Ltd) for $1 \mathrm{~h}$. The sections were then incubated with the anti-PR antibody diluted 1:20 in blocking serum for $18 \mathrm{~h}$ at $4{ }^{\circ} \mathrm{C}$. After rinsing, the slides were incubated with a 1:200 dilution of biotinylated horse antimouse antibody (Vector Laboratories Ltd) for $1 \mathrm{~h}$ at room temperature. After rinsing, antibody binding was visualised using an avidin-biotin horseradish peroxidase detection system (Vector Laboratories Ltd) with diaminobenzidine and nickel to give a black end-product. Sections were dehydrated, cleared and mounted in pertex medium (Cellpath plc, Newtown, Powys, UK) without counterstaining. Sections of luteal phase endometrium were used as positive controls and the primary antibody was replaced by non-specific mouse immunoglobulins in the negative controls.

Immunostaining for aromatase and $17 \alpha$-hydroxylase was carried out on serial sections. For aromatase, the block was normal rabbit serum diluted 1:5 with Tris-buffered saline (TBS) containing $50 \mathrm{mg} / \mathrm{ml}$ bovine serum albu$\min (B S A)$ and the primary antibody was used in a 1:100 dilution in the block. The secondary antibody was biotinylated rabbit anti-mouse (DAKO Ltd, Ely, Cambs, UK) diluted 1:400 in the block. For $17 \alpha$-hydroxylase, the block was normal swine serum diluted 1:5 with TBS containing $50 \mathrm{mg} / \mathrm{ml}$ BSA and the primary antibody was used in 
a 1:500 dilution in TBS. The secondary antibody was a biotinylated swine anti-rabbit (DAKO Ltd) diluted 1:200 with TBS. For both, an avidin-biotin-alkaline phosphatase detection system was used with nitroblue terazolium (NBT) to give a blue end-product.

\section{Analysis of immunohistochemistry results}

The different cell types were identified in each section by morphological assessment and reference to serial sections immunostained for aromatase and $17 \alpha$-hydroxylase. Using this protocol, the granulosa-lutein cells, theca-lutein cells and surrounding stromal fibroblasts could be identified in each tissue analysed. The overall intensity of PR staining in these three compartments was assessed by an observer blinded to the tissue identity. Black nuclear staining identified PRs and staining intensity was graded as absent (0), low (1), moderate (2), high (3) or very high (4). Grading was repeated at a later date to confirm excellent intraobserver variation. Another blinded observer also graded the tissues to confirm excellent inter-observer variation $(r>0.8$ in each case).

The intensity of staining at different stages of the luteal phase in the various cellular compartments was analysed using a Kruskal-Wallis test. Levels of significance were taken as $P<0.05$ and, where significant, pairwise comparisons were carried out using Dunn's multiple comparison tests (MCTs). Differences in staining intensity between theca-lutein and granulosa-lutein cells were analysed using a Mann-Whitney test.

\section{Collection of luteinised granulosa cells}

The Reproductive Medicine Subcommittee of the Lothian Medical Ethics Committee separately approved the collection of luteinised granulosa cells from patients undergoing assisted conception. Follicular fluid was collected from women undergoing transvaginal oocyte retrieval for in vitro fertilisation following ovarian stimulation using a standard procedure (Stamouli et al. 1996). Briefly, a long protocol stimulated cycle was followed, using nasal naferelin (Pharmacia, Milton Keynes, Bucks, UK) for downregulation and daily purified gonadotrophins (Menopur; Ferring Pharmaceuticals, Langley, Berks, UK) for ovarian stimulation. When at least three follicles reached $18 \mathrm{~mm}$ in diameter, 10000 IU hCG was administered. Transvaginal oocyte collection was performed under sonographic guidance $35 \mathrm{~h}$ later.

Granulosa cells were obtained from the follicular aspirates after the removal of the oocytes. Individual follicles were not distinguished and all follicular fluid from the same individual was pooled and centrifuged at 1500 r.p.m. for $10 \mathrm{~min}$. The cells were resuspended in culture medium (Dulbecco's minimum essential medium/F12 Ham mixture; Gibco BRL, Gaithersburg, MD, USA), layered over a $45 \%$ Percoll/culture medium mixture (Aston et al. 1996) and centrifuged at 1200 r.p.m. for
$30 \mathrm{~min}$ to pellet the blood cells. Luteinised granulosa cells, visible in the interface, were collected by pipette and washed three times in phosphate-buffered saline (PBS). The cells were resuspended in culture medium and viable cells were counted using a Trypan blue exclusion test. Eighty thousand viable cells were plated onto each well of 24-well plates pre-coated with Matrigel (Aston et al. 1996, Stamouli et al. 1996) and cultured using $1 \mathrm{ml}$ culture medium at $37^{\circ} \mathrm{C}$ in $5 \% \mathrm{CO}_{2}$ in air.

\section{Culture of luteinised granulosa cells}

Cells were cultured for up to 13 days using culture medium supplemented with glutamine $(2 \mathrm{mmol} / \mathrm{l})$, insulin $(6.25 \mathrm{mg} / \mathrm{l})$, transferrin $(6.25 \mathrm{mg} / \mathrm{l})$, selenious acid $(6.25 \mu \mathrm{g} / \mathrm{l})$, amphoteracin $(2.5 \mathrm{mg} / \mathrm{l})$, penicillin $(50 \mathrm{mg} / \mathrm{l})$ and streptomycin $(60 \mathrm{mg} / \mathrm{l})$ as described previously (Aston et al. 1996). Media were changed every $2-3$ days over the course of the culture period and stored at $-20^{\circ} \mathrm{C}$ for subsequent progesterone assessment. Until day 7 of culture the media were supplemented with $1 \mathrm{ng} / \mathrm{ml}$ hCG and $50 \mathrm{mg} /$ low density lipoproteins (LDL). On the seventh day of culture the hCG was either increased to $100 \mathrm{ng} / \mathrm{ml}$ or withdrawn. One experimental arm, where the hCG was increased to $100 \mathrm{ng} / \mathrm{ml}$ after 7 days, included aminoglutethamide $(100 \mu \mathrm{M})$ throughout the culture period to inhibit progesterone synthesis.

\section{Measurement of progesterone}

Progesterone concentrations in media collected on days $2-3$, day 7 and days $11-13$ of culture and in the women's preoperative serum were measured using a plate modification of a standard in-house progesterone radioimmunoassay. This assay typically had an intra-assay co-efficient of variation (C.V.) of $<4 \%$, an interassay C.V. of $<11 \%$ and a detection limit of $0.1 \mathrm{nmol} / \mathrm{l}$.

\section{Immunocytochemistry}

In some experiments, cultured granulosa cells were removed from the culture wells using a trypsin and EDTA solution and resuspended in a solution of culture medium containing 10\% fetal bovine serum. The cells were pelleted, washed in PBS and fixed in 10\% formaldehyde for $10 \mathrm{~min}$. After centrifugation to pellet the cells, they were further washed in PBS and resuspended in $2 \%$ low melting point agarose prepared in PBS. The mixture was pipetted into moulds and allowed to solidify at room temperature. These moulds were then processed into paraffin blocks for subsequent immunocytochemistry. The immunocytochemical procedure followed the protocols described above. For the dual-staining immunocytochemistry, the first antibody used was the anti-PR antibody (Maybin \& Duncan 2004). After the protocol was complete, the slides were rinsed in distilled water for $5 \mathrm{~min}$ and the protocol for the second $3 \beta-\mathrm{HSD}$ antibody was followed. For $3 \beta-\mathrm{HSD}$, the block used was normal goat serum diluted 1:67 with PBS (DAKO Ltd) and the primary 
antibody was used in a 1:1000 dilution in block. The secondary antibody was a biotinylated goat anti-rabbit $\lg \mathrm{G}$ diluted 1:200 with block (DAKO Ltd) and an avidin-biotin horseradish peroxidase detection system was used with diamino-benzidine (DAB) to give a brown end-product.

\section{Preparation of cDNA}

For estimation of PR mRNA expression, the experiment was carried out on four separate occasions using luteinised granulosa cells from different women. Each experiment was carried out with six replications of each time-point and cells from two identical wells were combined prior to RNA extraction. Cells were studied at days $2-3$, day 7 and days 11-13 of culture. After removal of culture medium at these time-points cells were rinsed in PBS and Tri-reagent was added. The resulting solution was stored at $-70^{\circ} \mathrm{C}$ until batch extraction of RNA from that experiment was carried out. RNA was extracted following the manufacturer's instructions. To remove contaminating genomic DNA, RNA was treated with DNAse I at a concentration of $1 \mathrm{U} / \mu \mathrm{g}$ RNA for $30 \mathrm{~min}$ at $37^{\circ} \mathrm{C}$. After stopping the reaction with stop solution the samples were heated to $70^{\circ} \mathrm{C}$ for $10 \mathrm{~min}$.

Using random hexamers, 200 ng RNA was reverse transcribed in a solution containing $5.5 \mathrm{mM} \mathrm{MgCl} 2,2.5 \mu \mathrm{M}$ random hexamers, $500 \mu \mathrm{M}$ of each dNTP, $0.4 \mathrm{U} / \mu$ l RNase inhibitor and $1.25 \mathrm{U} / \mu \mathrm{l}$ multiscribe reverse transcriptase (PE Applied Biosystems, Warrington, Cheshire, UK). Samples were incubated at room temperature for $10 \mathrm{~min}$, followed by $42{ }^{\circ} \mathrm{C}$ for $60 \mathrm{~min}$ and $95^{\circ} \mathrm{C}$ for $10 \mathrm{~min}$. Two controls were used, one omitted the multiscribe enzyme and the other the template RNA. cDNA from human corpora lutea $(n=12)$ was prepared using the same techniques.

\section{Real-time quantitative RT-PCR}

Real-time quantitative PCR was used to quantify the amount of PR A/B isoform mRNA using a Taqman PCR reaction. The amplification of PR message was related to ribosomal 18S RNA and to an internal control as described previously (Henderson et al. 2003). The 18 S primer and probe were purchased from PE Applied Biosystems. The PR primer/probe set was designed to span an intron to reduce spurious readings due to genomic DNA contamination. The following sequences used were $\left(5^{\prime}-3^{\prime}\right)$ : forward primer CAGTGGGCGTTCCAAATGA; reverse primer TGGTGGAATCAACTGTATGTCTTGA; probe AGCCAAGCCCTAAGCCAGAGATTCACTTT (Henderson et al. 2003). Each sample was run in duplicate and each run contained both controls using the ABI PRISM 7700 (PE Applied Biosystems) under standard conditions (Henderson et al. 2003).

Quantitative RT-PCR to investigate the expression of the PR B isoform mRNA was carried out using a LightCycler DNA Engine (MJ Research Inc., Watertown, MA, USA).
The primers used were $\left(5^{\prime}-3^{\prime}\right)$ : forward ACACCTTGCCTGAAGTTTCG and reverse CTGTCCTTTTCTGGGGGACT. The assay was optimised for annealing temperature $\left(64^{\circ} \mathrm{C}\right)$ and $\mathrm{MgCl}_{2}$ concentration $(3 \mathrm{mM})$. Products were examined by gel electrophoresis to confirm the presence of a single band at the correct size, and to confirm the optimal conditions. All assays exhibited a single DNA melting curve peak. Quantitative real-time PCR was performed in duplicate $10 \mu \mathrm{l}$ reaction volumes on the LightCycler using the Mastermix supplied with the Fast Start DNA Master SYBR Green1 kit (Roche, Lewes, E Sussex, UK), at the optimised conditions. A standard curve was generated using serial dilutions of standardised cDNA using the 2nd derivative maximum method provided in the LightCycler software (version 3.3). PCR product concentrations were automatically calculated for the sample by the software, by comparing the sample threshold cycle to the standard curve. In all cases, the level of gene expression within the samples lay within the boundaries of the corresponding standard curve. All samples were analysed in duplicate and assay variation was typically within $10 \%$. Data were normalised according to the expression level of glucose-6phosphate dehydrogenase (G6PDH) determined in duplicate.

\section{Analysis of quantitative RT-PCR}

Statistical analysis was carried out using ANOVA after normalisation by logarithmic transformation. Where significant differences $(P<0.05)$ were detected, pair-wise comparisons were carried out using the Tukey-Kramer MCTs.

\section{Results}

\section{Localisation of different cells in human corpora lutea}

Genomic PRs could be localised to the nucleus of cells in the corpus luteum in all sections studied. Specific nuclear staining was also detected in an early luteal endometrial biopsy used as a positive control and was absent from all negative control sections. Three major cell layers could be identified morphologically in sections of human corpus luteum, the stroma, the steroidogenic cells and the central clot (Fig. 1a). The granulosa-lutein cells, in the steroidogenic cell layer, were identified by immunohistochemistry for aromatase (Fig. 1b) and theca-lutein cells by immunostaining for $17 \alpha$-hydroxylase (Fig. 1c). The stromal cells were defined as the cells peripherally surrounding the steroidogenic cells and were identified morphologically (Fig. 1a and d).

\section{PR immunohistochemistry across the luteal phase}

Nuclear PRs could be identified in sections of corpora lutea from all stages of the luteal phase and after luteal rescue with hCG (Fig. 2). When the intensity of PR staining was graded (Fig. 3), there were differences 

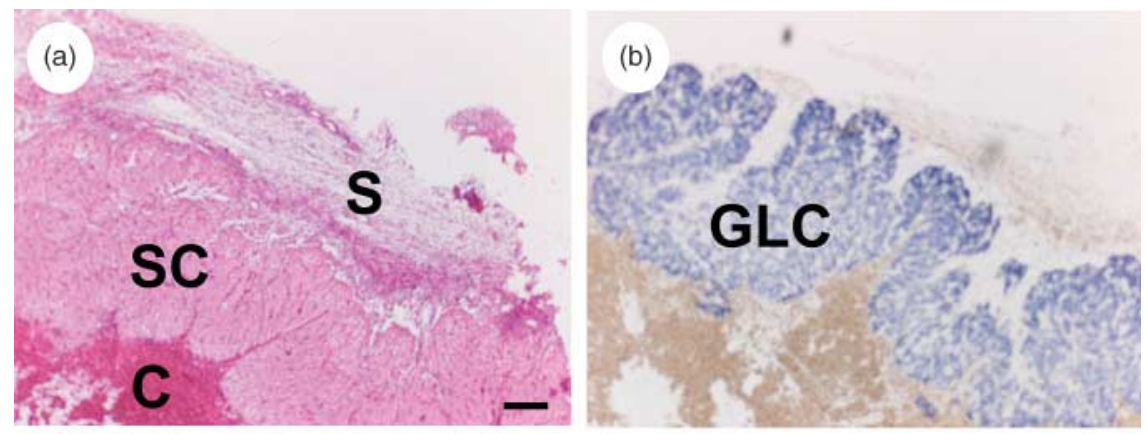

(c)

(d)
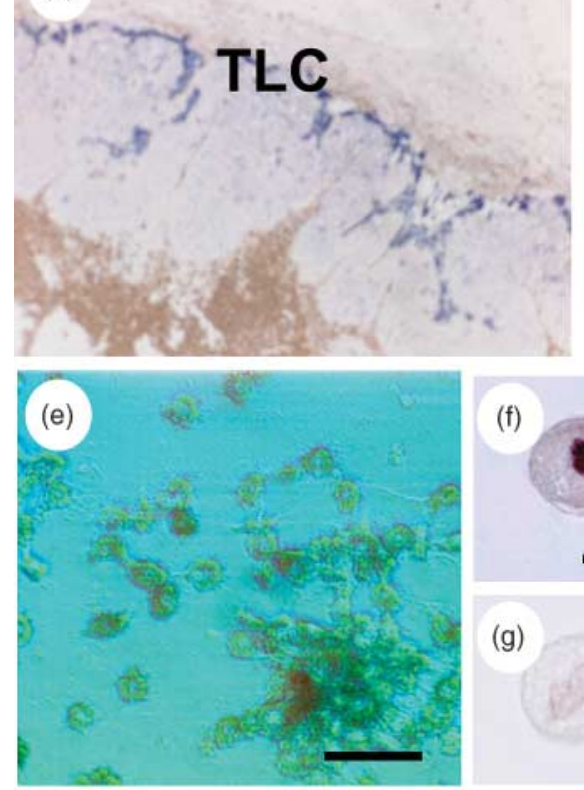

(f)
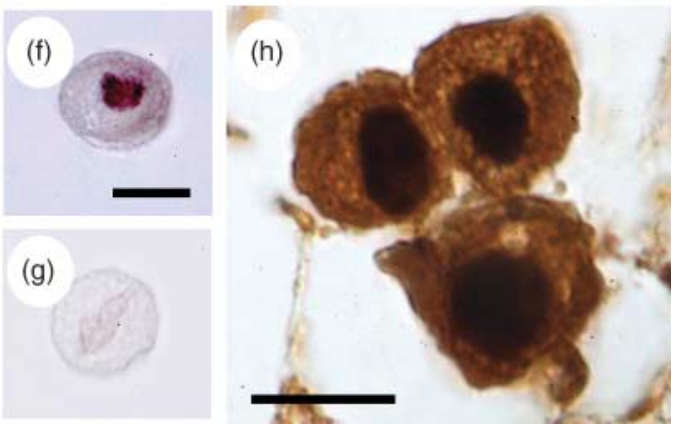

Figure 1 (a) Low power photomicrograph of a mid-luteal $(\mathrm{LH}+6)$ corpus luteum, after haematoxylin and eosin staining, clearly showing the central fibrous clot (C), the steroidogenic cell layer (SC) and the surrounding stromal cells (S). (b) Granulosa-lutein cells (GLC) are seen in a serial section immunostained for aromatase (blue staining) at the same magnification. (c) Theca-lutein cells (TLC) were identified (blue staining) around the periphery of the granulosa-lutein cells in a serial section immunostained for $17 \alpha$-hydroxylase at the same magnification. (d) Another serial negative control section where the central clot $(\mathrm{C})$, steroidogenic cells (SC) and stromal cells (S) can still be identified. (e) Luteinised granulosa cells in culture. (f) Cultured luteinised granulosa cell after immunocytochemistry for PR showing specific nuclear staining (black). (g) No immunostaining was visible in the negative control luteinised granulosa cell at the same magnification. (h) Luteinised granulosa cell dual stained for $3 \beta-\mathrm{HSD}$ (brown) and PRs (black), confirming that the cells producing progesterone have the potential to respond to it. Scale bars (a and d) $100 \mu \mathrm{m}$, (e) $20 \mu \mathrm{m}$ and ( $\mathrm{f}$ and h) $5 \mu \mathrm{m}$. at different functional stages of the luteal phase in the granulosa-lutein cells $(P<0.05)$ (Fig. 3a). When compared with the early luteal phase, staining intensity was lower in the late-luteal phase $(P<0.05)$ and tended to be lower after luteal rescue $(P=0.0538)$. This pattern of change in PR immunostaining intensity was not seen in theca-lutein cells where there were no stage-specific differences (Fig. 3a). This meant that in the late-luteal phase $(P<0.01)$ and after luteal rescue $(P<0.05)$, granulosa-lutein cell PR immunostaining intensity was less than theca-lutein cell immunostaining intensity (Fig. 3a). There were no changes in stromal PR immunostaining at different functional stages of the luteal phase (Fig. 3b).

\section{PR mRNA expression in human corpora lutea}

mRNA was available for 12 of these corpora lutea $(n=3$ per stage). The expression of genomic PR was therefore investigated by quantitative RT-PCR to investigate whether the changing pattern of PR immunostaining across the cycle could be detected at the level of mRNA expression. There were no differences in PR mRNA expression at different stages of the luteal phase (Fig. 4a). However, the expression of PR mRNA was similar in the rescued corpora lutea (Fig. 4a), with continued functional integrity (Fig. 4b), and the late-luteal phase, where functional integrity was being lost (Fig. 4b).

\section{PRs in luteinised granulosa cells}

As the proportion of different cell types may change across the luteal phase, and changes in PR expression may vary in different cell types, PR mRNA expression in the granulosa-lutein cells was specifically investigated using an in vitro model system. PR expression was studied in luteinised granulosa cells in primary culture (Fig. 1e). Cultured luteinised granulosa cells also showed positive immunostaining for nuclear PRs (Fig. 1f) that was not seen in negative control sections (Fig. 1g). These cells expressed both $3 \beta-$ HSD and genomic PRs and these could be co-localised by dual-staining immunocytochemistry (Fig. 1h).

\section{The effect of hCG on luteinised granulosa cell PRs}

A model was designed to mimic the stages of the luteal phase. After 7 days in culture with low concentrations of 

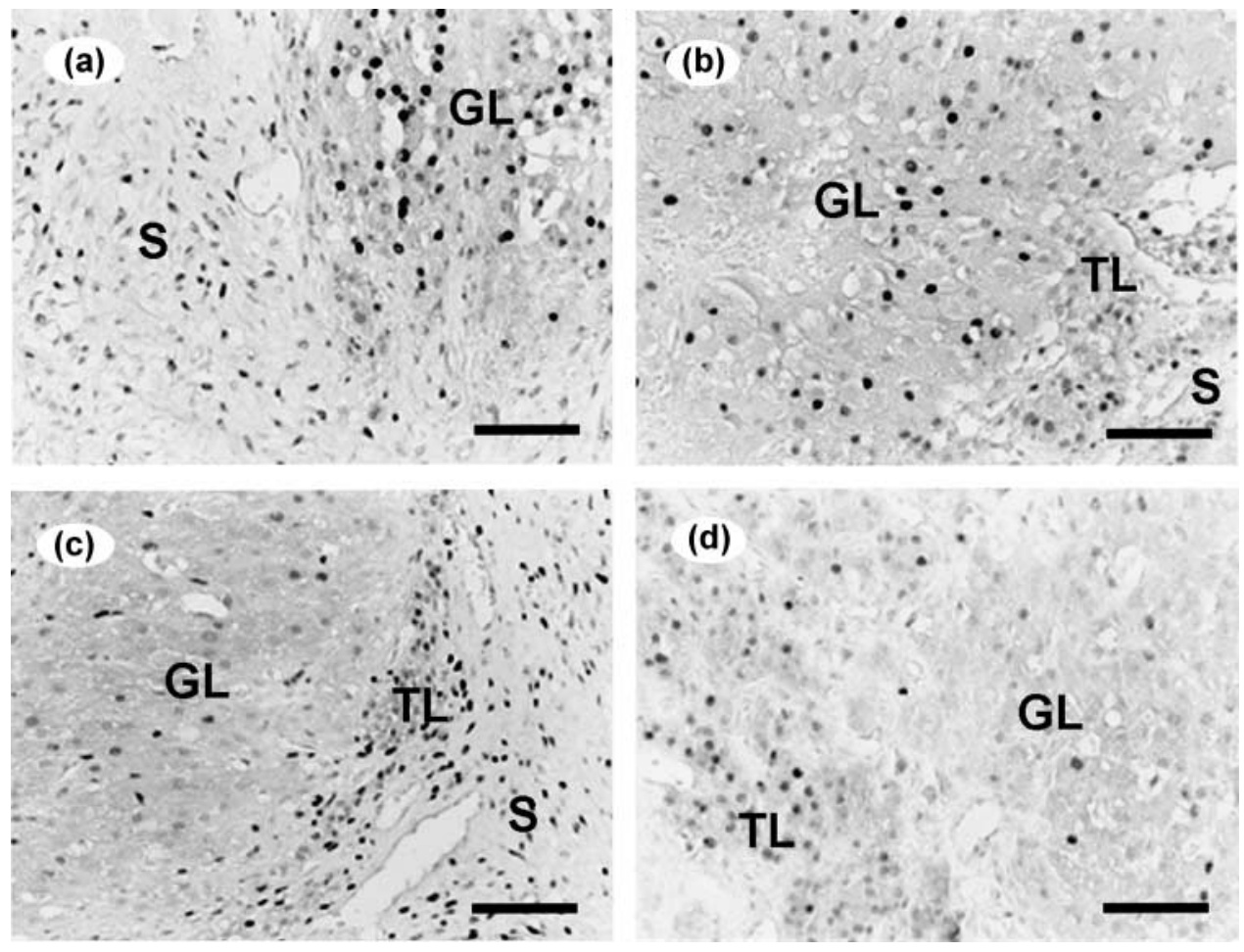

Figure 2 (a) An example of an early luteal human corpus luteum after immunostaining for genomic PRs (black staining). Staining can be seen in the stroma $(\mathrm{S})$ and the granulosa-luteal cells (GL). (b) Immunohistochemical staining of a mid-luteal corpus luteum showing PRs in the stroma, granulosalutein cells and theca-lutein cells (TL). (c) A typical late-luteal corpus luteum showing PR immunostaining in all three cell types. (d) Section of a corpus luteum rescued with exogenous hCG immunostained for PRs. Note the apparent reduced intensity of PR staining in the GL cells in both the late-luteal phase and after luteal rescue with hCG when compared with earlier sections. Scale bars $50 \mu \mathrm{m}$.
hCG, the hCG was either increased to simulate luteal rescue or removed to simulate luteolysis. In addition, the experiments were repeated in the presence of aminoglutethamide in an attempt to separate the effects of hCG from those of progesterone. The concentration of progesterone in the culture medium is shown in Fig. 5a. Progesterone concentrations were higher after 11-13 days of culture in the presence of hCG than in the absence of hCG $(P<0.001)$, or the presence of hCG and aminoglutethamide $(P<0.001)$.

PR mRNA in the cultured luteinised granulosa cells was quantified using real time RT-PCR (Fig. 5b). PR expression changed over the course of the culture $(P<0.05)$. There was a significant reduction in PR mRNA expression from day 7 to days 11-13 of culture in the absence of hCG $(P<0.05)$. This reduction could not be inhibited by presence of hCG where progesterone exposure was maintained $(P<0.05)$ or withdrawn $(P<0.05)$. This pattern was identical to the pattern seen in the granulosa-lutein cells in vivo (Fig. 3a). The expression of the B isoform of the PR was also investigated using this model system (Fig. 5c). Although the differences at different stages of culture were not quite significant $(P=0.0554)$, the pattern was remarkably similar to that of $\mathrm{PR} A / \mathrm{B}$ mRNA expression.

\section{Discussion}

There is no doubt that corpora lutea of women and other non-human primates express genomic receptors to the progesterone they produce. We have confirmed the published observations in women (Iwai et al. 1990, Ottander et al. 2000), rhesus monkeys (Hild-Petito et al. 1988) and baboons (Hild-Petito \& Fazleabas 1997) on luteal PR immunostaining. Where PR expression has been quantified there is a clear trend to its reduction in the late-luteal phase in most published studies. This is the case using immunohistochemistry and protein assays in women (Iwai et al. 1990, Ottander et al. 2000) and immunohistochemistry and Western blotting in non-human primates (Duffy et al. 1997, Hild-Petito \& Fazleabas 1997). Using wellcharacterised human corpora lutea we have confirmed that the PR immunostaining is reduced in the late-luteal phase.

This paper takes these observations forward by investigating the corpus luteum of simulated early pregnancy. It has been suggested that a specific PR-mediated action in the steroidogenic cells of the human corpus luteum may maintain function during early pregnancy (Ottander et al. 2000). The fall in PR expression during the late-luteal phase may therefore be involved in the luteolytic process by augmenting progesterone withdrawal. We have previously shown that for various structural and functional characteristics, the rescued corpus luteum of early pregnancy is more similar to the corpus luteum of the early and mid-luteal phase than the late-luteal corpus luteum entering luteolysis (Duncan et al. 1996, 1998a, 1998b, 1999). We therefore hypothesised that, if progesterone is important in the maintenance of luteal function during early pregnancy, genomic PR expression would be maintained by hCG in the rescued corpus luteum.

This is not what we found in these studies. Treatment with hCG in vivo to mimic early pregnancy 
(a)

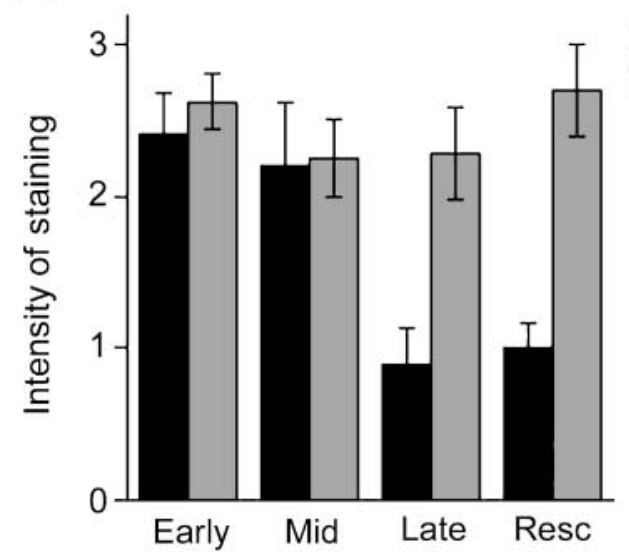

(b)

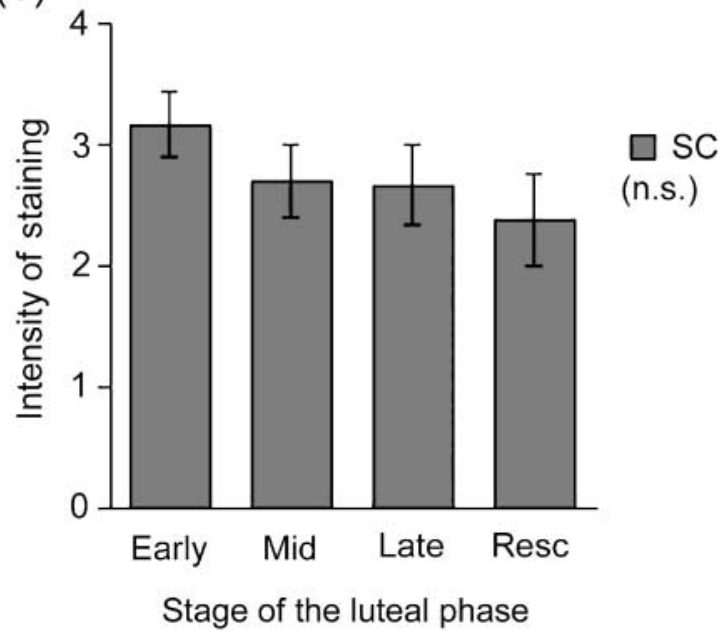

Figure 3 PR staining intensity across the luteal phase. (a) Intensity of staining in the granulosa-lutein cells (GLC) and theca-lutein cells (TLC). There is no difference in TLC immunostaining at different stages of the luteal phase (Kruskal-Wallis). There are differences, however, in GLC immunostaining at different stages of the luteal phase $(P<0.05$, Kruskal-Wallis), with both late and rescued tending to be lower. (b) Intensity of staining in the stromal cells (SC) showing no differences across the stages of the luteal phase (Kruskal-Wallis). n.s. $=$ non-significant, Early $=\mathrm{LH}+1$ to $\mathrm{LH}+5(n=11)$, $\mathrm{Mid}=\mathrm{LH}+6$ to $\mathrm{LH}+10(n=10)$, Late $=\mathrm{LH}+11$ to $\mathrm{LH}+14$ $(n=9)$ and Resc $=5-8$ days of hCG from $\mathrm{LH}+7(n=5)$.

does not appear to maintain PR immunostaining in the granulosa-lutein cells of the corpus luteum. Indeed, in this regard, immunostaining of the rescued corpus luteum has more in common with the late-luteal phase than the early and mid-luteal phases. As these observations were semiquantitative, using non-parametric comparisons, we attempted to confirm this finding by investigating PR mRNA expression in corpora lutea. This proved unsatisfactory, probably because of the small numbers available. However, in whole corpora lutea the effect of changing expression in only one cell type, with maintenance in other cells, combined with changes in luteal cell composition over the luteal phase means that changes in PR
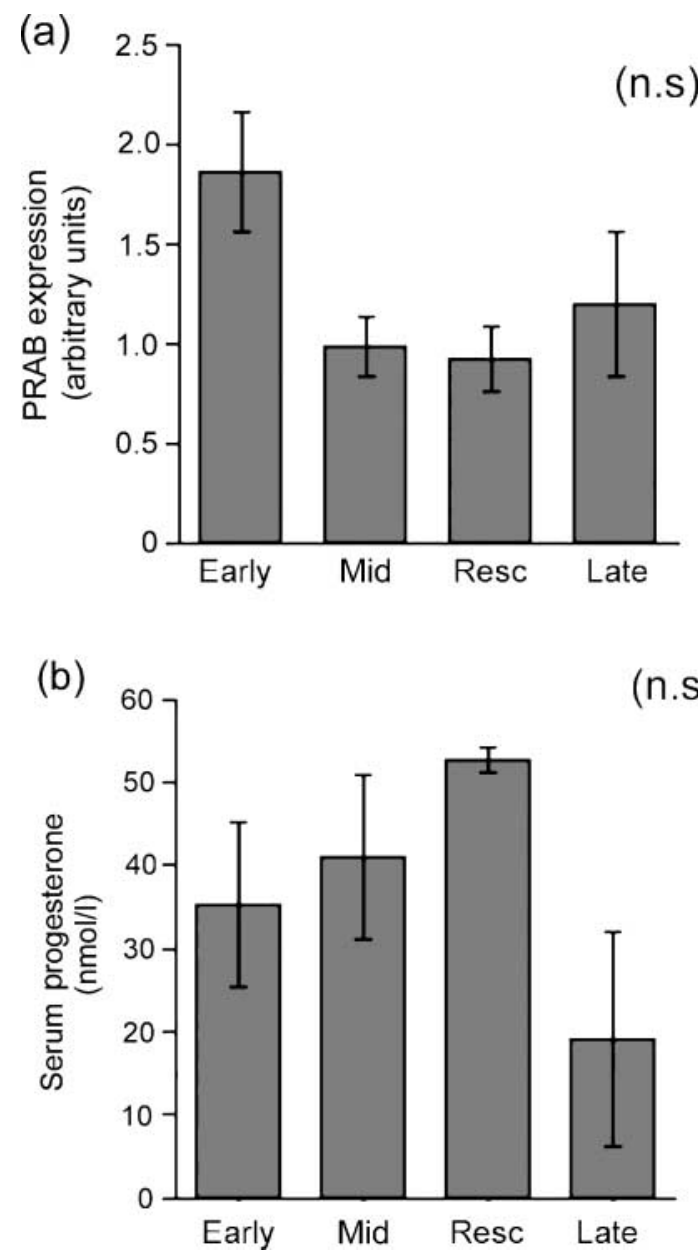

Figure 4 (a) The expression of mRNA for PR (the assay recognises both the $\mathrm{A}$ and $\mathrm{B}$ form of the receptor) in human corpora lutea at different stages of the luteal phase using quantitative RT-PCR. (b) Serum progesterone in women at different stages of the luteal phase showing the trend for progesterone to increase in luteal rescue and to fall in the late-luteal phase. There are no significant differences (ANOVA). n.s. $=$ non-significant, Early $=\mathrm{LH}+1$ to $\mathrm{LH}+5(n=3)$, $\mathrm{Mid}=\mathrm{LH}+6$ to $\mathrm{LH}+10(n=3), \operatorname{Resc}=5-8$ days of hCG from $\mathrm{LH}+7(n=3)$ and Late $=\mathrm{LH}+11$ to $\mathrm{LH}+14(n=3)$.

expression may be masked. We therefore developed an in vitro model to test our in vivo observations of changes in granulosa-lutein cells. Over 12-13 days of culture, luteinised granulosa cells demonstrated reduced PR mRNA expression. This cannot be reversed by hCG treatment to maintain and increase progesterone secretion. The pattern of PR expression in granulosa-lutein cells in vivo and luteinised granulosa cells in vitro, and the effect of hCG was remarkably consistent. Both suggest that hCG does not maintain PR expression. This is not consistent with progesterone having a major direct role in the maintenance of granulosa-lutein cell function in early pregnancy.

The effect of pregnancy on luteal PRs has been investigated in non-human primate models. Hild-Petito \& Fazleabas (1997) suggested that, in the baboon, luteal PRs 
were maintained in early pregnancy. It was clear that the percentage of PR-positive cells tended to be lower than in the mid-luteal phase and distinctions between granulosalutein, theca-lutein and stromal cells were not made (Hild-Petito \& Fazleabas 1997). In addition, the decline in $3 \beta-H S D$ staining in early pregnancy, which is not seen in women (Duncan et al. 1999), suggests possible species differences. In another study using the rhesus macaque, some luteal cells continued to show PR immunostaining in early pregnancy but the number of staining cells declined and the nature of these cells was not clear (Duffy \& Stouffer 1997). The differences in the late-luteal phase and pregnancy are not seen when PR mRNA is analysed in the primate corpus luteum (Duffy \& Stouffer 1995). It is possible that differential translation is involved (Stouffer 2003) but, as PRs appear to be differentially regulated in different cell types, the cellular composition of the extracted tissues may dilute any compartmental changes. However, all studies, including ours, suggest that although PR immunostaining changes, protein and mRNA can be detected at all stages of the luteal phase (Stouffer 2003). It is likely, however, that there is some down-regulation of $\mathrm{PR}$ in the corpus luteum of early pregnancy.

We have shown that the down-regulation of PRs in the late-luteal phase is confined to the granulosa-lutein cells. There are no changes in theca-lutein or stromal PR immunostaining across the luteal phase. Although this has not been reported previously, there was a suggestion, in the small number of corpora lutea studied by Suzuki et al. (1994), that there might be differential PR regulation in the different types of steroidogenic cell. It is unclear which mechanism is involved in these differential effects.

We have demonstrated that stromal PR immunostaining is maintained throughout the luteal phase. There is quite a marked symmetry with what happens to PRs in the endometrium during the luteal phase of the cycle. During the secretary phase of the cycle stromal PR immunostaining is maintained throughout (Koh et al. 1995) but glandular immunostaining is down-regulated by the mid-luteal phase. Of particular interest is the fact that in the lateluteal phase, when progesterone concentrations are falling or where they are maintained by hCG, using our model the glandular PR remain down-regulated (Koh et al. 1995). The luteal stromal cell PR expression behaves like stromal cells in the endometrium and breast (Graham \& Clarke 1997) and it is not surprising that its expression continues.

The mechanism of PR down-regulation in granulosalutein cells is not clear. In the endometrium, progesterone down-regulates its own receptor in the endometrial glands as treatment with a PR antagonist maintains endometrial glandular PR expression (Cameron et al. 1996). Indeed, inhibition of progesterone synthesis by trilostane resulted in time-dependant increases in PR mRNA expression in macaque luteal tissue at the mid-luteal phase (Duffy \& Stouffer 1995) and in stimulated early pregnancy (Duffy \& Stouffer 1997). This suggests that progesterone may be

Reproduction (2005) 130 83-93 involved in the down-regulation of the luteal receptor as seen in other tissues (Graham \& Clark 1997). However, the timing of down-regulation is different. In the endometrium, down-regulation is complete in the mid-luteal phase (Koh et al. 1995) but it is only seen in the late-luteal phase in the corpus luteum. In addition, in vivo studies of luteal PR may be affected by changes in cellular composition of the corpus luteum. Whether progesterone itself is responsible for the differential down-regulation of $P R$ in the human corpus luteum is still not entirely clear.
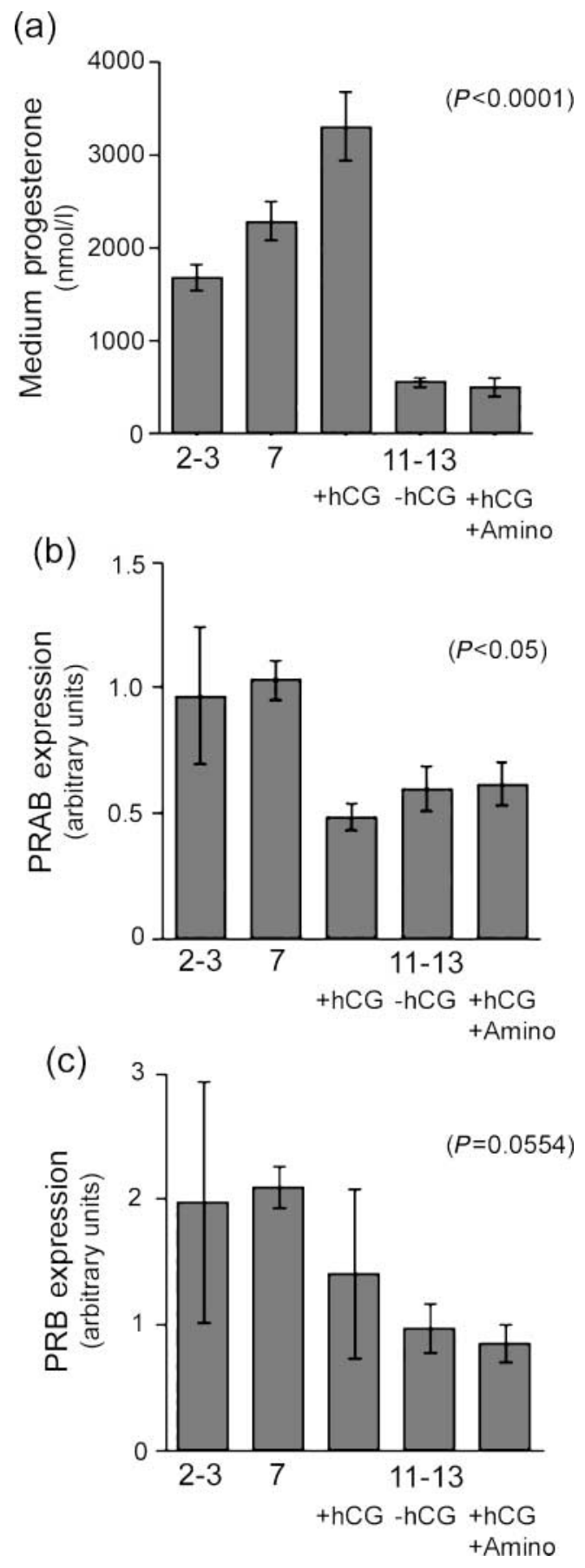

www.reproduction-online.org 
In an attempt to determine if progesterone was involved in the down-regulation of PR seen in luteinised granulosa cells in culture, we inhibited steroidogenesis throughout the culture period using aminoglutethamide. This reduced progesterone synthesis to basal levels and did not reverse the down-regulation. This is not consistent with progesterone down-regulation of its receptor but effects of basal concentrations of progesterone have not been excluded. Such an in vitro model of corpus luteum function can be criticised. It is recognised that various cell types and paracrine communication systems are not present. Other researchers have argued for the use of luteinised granulosa cell cultures as a model of luteal function (Aston et al. 1996, Stamouli et al. 1996). They have described valuable insights into the control of enzymes involved in remodelling that mirror the findings of our in vivo model (Stamouli et al. 1996, Duncan et al. 1998a). One thing this model tells us is that the effects of progesterone seen early in the culture of luteinised granulosa cells (Greenberg et al. 1990) may be different from those after longer culture in the presence of progesterone.

There are two main isoforms of the $P R$, the ' $A$ ' form and the ' $B$ ' form. Generally PR B mediates the stimulatory effects of progesterone in classical target tissues while PR A can inhibit the ability of PR B to stimulate transcription. In most progesterone-responsive tissues both the $\mathrm{A}$ and $\mathrm{B}$ isoforms co-exist. There is some confusion about the relative amounts of each in the corpus luteum. In mice, some authors have found that granulosa cell PR A is higher than PR B but PR is lost during luteinisation (Shao et al. 2003), and others have found PR B to be predominant in the granulosa cell and present in the corpus luteum (Gava et al. 2004). In the primate corpus luteum, Western blotting suggested that the major PR variant is the B isoform (Duffy et al. 1997). In human corpora lutea, however, PR A/B mRNA was found in higher concentrations than PR B mRNA (Misao et al. 1998, Ottander et al. 2000) and PR A was confirmed to be higher using Western blotting (Misao et al. 1998). It seems clear, however, that both PR isoforms are expressed in the corpus luteum.

Whether there are any differential changes in PR isoforms in different cellular compartments across the luteal phase is not known. In the endometrium, both isoforms are found in glandular tissue and are down-regulated in the secretary phase and it appears that in the secretary phase the stromal PR is primarily the A isoform (Wang et al. 1998). Whether this corresponds to the stromal PR in the corpus luteum is not known. It has been suggested, however, that there may be differential control of the $A$ and $B$ form of the receptor in the corpus luteum (Duffy et al. 1997, Stouffer 2003). In the non-human primate, PR A levels decreased throughout the luteal phase while PR B remained unchanged (Duffy et al. 1997). However, in the human corpus luteum, both PR A and PR B isoforms were reduced in the late-luteal phase (Misao et al. 1998). Certainly the pattern of PR B expression in luteinised granulosa cells is similar to that of PR A/B in our experiments. It is likely that PR $A$ and $P R B$ are similarly regulated in granulosa-lutein cells but differential regulation in other cell types remains to be investigated.

It has been appreciated for a long time that not all the effects of progesterone can be explained by genomic PRs (Bramley 2003). Two potential related membrane PRs have recently been cloned and sequenced (Zhu et al. 2003). These have a wide expression profile. It is still not known whether these are expressed on the various cell types in the human corpus luteum but it is known that the corpus luteum does have membrane-linked progesteronebinding activity (Bramley et al. 2002). The role of these receptors is not clear but their presence offers further potentials for progesterone as a paracrine-signalling molecule in cells whose genomic PRs are down-regulated. Indeed, the differential down-regulation of PR in the corpus luteum does not mean that progesterone does not have effects on luteal function (Stouffer 2003). The endometrium is a major target tissue for progesterone and progesterone withdrawal produces marked remodelling (Salamonsen et al. 1997) despite down-regulation of PR in some compartments. Even though granulosa-lutein cell PR is reduced to some extent, PR expression in the thecalutein and stromal cells is maintained and progesterone action is possible.

However, the main question is whether progesterone has specific roles in luteal rescue. We hypothesised that if progesterone had a major role in the function of granulosa-lutein cells at the luteolysis, the down-regulation of

Figure 5 Cells were grown for 7 days in the presence of $1 \mathrm{ng} / \mathrm{ml} \mathrm{hCG} \mathrm{with} \mathrm{LDL.} \mathrm{Cells} \mathrm{and} \mathrm{culture} \mathrm{medium} \mathrm{were} \mathrm{collected} \mathrm{at} \mathrm{days} 2-3(2-3)$ and day 7 (7). After 7 days in culture, hCG was either removed $(0 \mathrm{ng} / \mathrm{ml})(11-13-\mathrm{hCG})$ or increased to $100 \mathrm{ng} / \mathrm{ml}(11-13+\mathrm{hCG})$. Cells and culture medium were collected on days 11-13 of each regimen. In another experimental arm, cells that followed the (11-13 + hCG) pattern were cultured with aminoglutethamide $(100 \mu \mathrm{M})$ for the duration of culture $(11-13+\mathrm{hCG}+$ Amino). (a) Progesterone concentrations in the medium at each time-point are different $(P<0.0001$, ANOVA). Progesterone is higher after 11-13 days in the presence of increased hCG than at day 7 $(P<0.05$, Tukey-Kramer MCT $)$. Progesterone is lower at days $11-13$ in the absence of hCG $(P<0.001$, Tukey-Kramer MCT $)$ or in the presence of hCG and aminoglutethamide $(P<0.001$, Tukey-Kramer MCT). (b) Expression of PR mRNA for A/B isoforms in cultured human luteinised granulosa cells measured by quantitative RT-PCR. There are differences over the course of the culture period $(P<0.05, \mathrm{ANOVA})$. There are no differences in expression between $2-3$ and 7 days in culture. After 11-13 days in culture after removal of hCG $(P<0.05$, Tukey-Kramer MCT), the increased exposure to hCG $(P<0.05$, Tukey-Kramer MCT $)$ or the exposure to hCG and aminoglutethamide $(P<0.05$, Tukey-Kramer MCT), the expression of PR A/B mRNA is reduced when compared with day 7 . (c) The same pattern of expression over the different stages of culture is apparent when PR B isoform mRNA is assessed by quantitative RT-PCR, although the differences are not quite significant $(P=0.0554$, ANOVA $)$. 
the PR in the late-luteal phase would not be seen during luteal rescue. This does not appear to be the case as we have evidence from both in vivo observational studies and in vitro interventional studies that the down-regulation of PR is not prevented by hCG. This does not mean that progesterone has no role in the function of luteinised granulosa cells as the corpus luteum ages but it does not support a major role for progesterone in the luteolysisluteal rescue transition.

\section{Acknowledgements}

The authors would like to acknowledge Dr Elena Faccenda and Professor Rodney Kelly for help with the quantitative RTPCR procedures. We also acknowledge Dr Hamish Fraser for continued support and helpful discussion of the manuscript. Dr Richard Anderson, Dr Peter Illingworth and their nursing support staff were involved in helping to recruit the women involved in this study. Dr Joo Thong helped provide the luteinised granulosa cells. We also acknowledge the skilled technical help of Clare Balfour. J A M was supported during her studentship by PPP Healthcare. W C D gratefully acknowledges the support of the Wellcome Trust. The authors declare that there is no conflict of interest that would prejudice the impartiality of this scientific work.

\section{References}

Aston KE, Stamouli A, Thomas EJ, Vyas S, Iredale JP, Arthur MJP \& Richardson MC 1996 Effect of gonadotrophin on cell and matrix retention and expression of metalloproteinases and their inhibitor in cultured human granulosa cells modelling corpus luteum function. Molecular Human Reproduction 2 26-30.

Behrman HR, Endo T, Aten RF \& Musicki B 1993 Corpus luteum function and regression. Reproductive Medicine Reviews 2 153-180.

Bramley T 2003 Non-genomic progesterone receptors in the mammalial ovary: some unresolved issues. Reproduction 125 $3-15$.

Bramley TA, Menzies GS, Rae MT \& Scobie G 2002 Non genomic steroid receptors in the bovine ovary. Domestic Animal Endocrinology 23 3-12.

Cameron ST, Critchley HOD, Buckley CH, Chard T, Kelly RW \& Baird DT 1996 The effects of post-ovulatory administration of onapristone on the development of a secretory endometrium. Human Reproduction 11 40-49.

Chaffin CL, Dissen GA \& Stouffer RL 2000 Hormonal regulation of steroidogenic enzyme expression in granulosa cells during the peri-ovulatory interval in monkeys. Molecular Human Reproduction 6 11-18.

Curry TE Jr \& Osteen KG 2003 The matrix metalloproteinase system: changes, regulation, and impact throughout the ovarian and uterine reproductive cycle. Endocrine Reviews 24 428-465.

Duffy DM \& Stouffer RL 1995 Progesterone receptor messenger ribonucleic acid in the primate corpus luteum during the menstrual cycle: possible regulation by progesterone. Endocrinology 136 $1869-1876$.

Duffy DM \& Stouffer RL 1997 Gonadotropin versus steroid regulation of the corpus luteum of the rhesus monkey during stimulated early pregnancy. Biology of Reproduction 57 1451-1460.

Duffy DM, Wells TR, Haluska GJ \& Stouffer RL 1997 The ratio of progesterone receptor isoforms changes in the monkey corpus luteum during the luteal phase of the menstrual cycle. Biology of Reproduction 57 693-699.
Duncan WC 2000 The human corpus luteum: remodelling during luteolysis and maternal recognition of pregnancy. Reviews of Reproduction 5 12-17.

Duncan WC, McNeilly AS, Fraser HM \& Illingworth PJ 1996 Luteinizing hormone receptor in the human corpus luteum: lack of down regulation during maternal recognition of pregnancy. Human Reproduction 11 2291-2297.

Duncan WC, Rodger FE \& Illingworth PJ 1998a The human corpus luteum: reduction in macrophages during maternal recognition of pregnancy. Human Reproduction 13 2435-2442.

Duncan WC, McNeilly AS \& Illingworth PJ 1998b The effect of luteal 'rescue' on the expression and localization of matrix metalloproteinases and their tissue inhibitors in the human corpus luteum. Journal of Clinical Endocrinology and Metabolism 83 $2470-2478$.

Duncan WC, Cowen GM \& Illingworth PJ 1999 Steroidogenic enzyme expression in human corpora lutea in the absence and presence of exogenous human chorionic gonadotrophin. Molecular Human Reproduction 5 291-298.

Gava N, Clarke CL, Byth K, Arnett-Mansfield RL \& DeFazio A 2004 Expression of progesterone receptors $\mathrm{A}$ and $\mathrm{B}$ in the mouse ovary during the estrous cycle. Endocrinology 145 3487-3494.

Graham JD \& Clarke CL 1997 Physiological action of progesterone in target tissues. Endocrine Reviews 18 502-519.

Greenberg LH, Stouffer RL, Brenner RM, Molskness TA, Hild-Petito SA \& Yu Q 1990 Are human luteinizing granulosa cells a site of action for progesterone and relaxin? Fertility and Sterility $\mathbf{5 3}$ 446-453.

Henderson TA, Saunders PTK, Moffet-King A, Groome NP \& Critchley HOD 2003 Steroid receptor expression in uterine natural killer cells. Journal of Clinical Endocrinology and Metabolism 88 440-449.

Hild-Petito S \& Fazleabas AT 1997 Expression of steroid receptors and steroidogenic enzymes in the baboon (Papio anubis) corpus luteum during the menstrual cycle and early pregnancy. Journal of Clinical Endocrinology and Metabolism 82 955-962.

Hild-Petito S, Stouffer RL \& Brenner RM 1988 Immunohistochemical localisation of estradiol and progesterone receptors in the monkey ovary throughout the menstrual cycle. Endocrinology 123 2896-2905.

Illingworth PJ, Reddi K, Smith K \& Baird DT 1990 Pharmacologic 'rescue' of the corpus luteum results in increased inhibin production. Clinical Endocrinology 33 323-332.

Iwai T, Nanbu Y, Iwai M, Taii S, Fujii S \& Mori T 1990 Immunohistochemical localization of oestrogen receptors and progesterone receptors in the human ovary throughout the menstrual cycle. Virchows Archive A (Pathology Anatomy Histology) 417 $369-375$.

Jones LS, Ottobre JS \& Pate JL 1992 Progesterone regulation of luteinizing hormone receptors on cultured bovine luteal cells. Molecular and Cellular Endocrinology 85 33-39.

Koh EAT, Illingworth PJ, Duncan WC \& Critchley HOD 1995 Immunolocalization of bcl-2 protein in human endometrium in the menstrual cycle and simulated early pregnancy. Human Reproduction $101557-1562$.

Li TC, Rogers AW, Dockery P, Lenton EA \& Cooke ID 1988 A new method of histologic dating of human endometrium in the luteal phase. Fertility and Sterility 50 52-60.

Makrigiannakis A, Coukos G, Christofidou-Solomidou M, Montas S \& Coutifaris C 2000 Progesterone is an autocrine/paracrine regulator of human granulosa cell survival in vitro. Annals of the New York Academy of Sciences 900 16-25.

Maybin JA \& Duncan WC 2004 The human corpus luteum: which cells have progesterone receptors? Reproduction 128 423-431.

Misao R, Nakanishi Y, Iwagaki S, Fujimoto J \& Tamaya T 1998 Expression of progesterone receptor isoforms in corpora lutea of human subjects: correlation with serum oestrogen and 
progesterone concentrations. Molecular Human Reproduction 4 1045-1052.

Morgan A, Keeble SC, London SN, Mase KN \& Curry TE Jr 1994 Antiprogesterone (RU486) effects on metalloproteinase inhibitor activity in human and rat granulosa cells. Fertility and Sterility $\mathbf{6 1}$ 949-955.

Ottander U, Hosokawa K, Liu K, Bergh A, Ny T \& Olofsson JI 2000 A putative stimulatory role of progesterone acting via progesterone receptors in the steroidogenic cells of the human corpus luteum. Biology of Reproduction 62 655-663.

Rothchild I 1996 The corpus luteum revisited: are the paradoxical effects of RU486 a clue to how progesterone stimulates its own secretion? Biology of Reproduction 55 1-4.

Salamonsen LA, Butt A, Hammond FR, Garcia S \& Zhang J 1997 Production of endometrial matrix metalloproteinases, but not their tissue inhibitors, is modulated by progesterone withdrawal in an in vitro model for menstruation. Journal of Clinical Endocrinology and Metabolism 82 1409-1415.

Shao R, Markström E, Friberg PA, Johansson M \& Billig H 2003 Expression of progesterone receptor (PR) $\mathrm{A}$ and $\mathrm{B}$ isoforms in mouse granulosa cells: stage dependent PR-mediated regulation of apoptosis and cell proliferation. Biology of Reproduction $\mathbf{6 8}$ 914-921.

Stamouli A, O'Sullivan MJB, Frankel S, Thomas EJ \& Richardson MC 1996 Suppression of matrix metalloproteinase production by hCG in cultures of human luteinized granulosa cells as a model for gon- adotrophin-induced luteal rescue. Journal of Reproduction and Fertility 105 235-239.

Stouffer RL 2003 Progesterone as a mediator of gonadotrophin action in the corpus luteum: beyond steroidogenesis. Human Reproduction Update 9 99-117.

Suzuki T, Sasano H, Kimura N, Tamura M, Fukaya T, Yajima A \& Nagura H 1994 Immunohistochemical distribution of progesterone, androgen and oestrogen receptors in the human ovary during the menstrual cycle: relationship to expression of steroidogenic enzymes. Human Reproduction 9 1589-1595.

Wang H, Critchley HOD, Kelly RW, Shen D \& Baird DT 1998 Progesterone receptor subtype $B$ is differentially regulated in human endometrial stroma. Molecular Human Reproduction 4 407-412.

Wulff C, Dickson SE, Duncan WC \& Fraser HM 2001 Angiogenesis in the human corpus luteum: simulated early pregnancy by HCG treatment is associated with both angiogenesis and vessel stabilization. Human Reproduction 16 2515-2524.

Zhu Y, Bond J \& Thomas P 2003 Identification, classification and partial characterization of genes in humans and other vertebrates homologous to a fish membrane progestin receptor. PNAS 100 2237-2242.

Received 27 February 2004

First decision 10 January 2005

Revised manuscript received 10 January 2005

Accepted 5 May 2005 